\title{
Poroba subjektu a nástroje jeho emancipace
}

\section{Robin Maialeh $^{1}$}

\begin{abstract}
Abstrakt: Tento text se zabývá širším pojetí svobody Člověka jako subjektu. V první části se autor snaží poodhalit zastřené a málo diskutované principy znemožňující plné sebeuskutečnění subjektů. Druhá část využívá poznatků tzv. třetí generace frankfurtské školy. $V$ rámci tohoto přístupu se profiluji dva významné proudy, inspirované hegelovskou a marxistickou tradicí. Jedná se tak o povrchní sjednocení „opozice“ současného liberálněkapitalistického konceptu ve věci svobody subjektu. $V$ poslední části autor objevuje nové perspektivy svobody subjektu prostřednictvím emancipačních nástrojů frankfurtské školy. Cílem bádání je klasifikovat postavení Člověka vůči Vnějšku; poskytnout ojedinělý pohled na dnešní nesvobodu a zároveň formulovat teoretickou bázi pro její možná řešení.
\end{abstract}

Klíčová slova: svoboda, člověk, odpovědnost, participace, uznání, společnost.

Abstract: The working paper deals with a broader concept of human freedom. The first part tries to reveal obscured principles that impede human self-realization. The second part makes use of findings of the third generation of the Frankfurt School. There we observe two main theoretical basis inspired by Hegelian and Marxian tradition. The text is thus a superficial unification of the opposition against contemporary liberally-capitalistic concept of human freedom. New perspectives of human freedom, derived from emancipation tools of the Frankfurt School, are shown within the last part. The aim of the paper is to classify a position of Man towards Outside; to provide a unique point of view on today's oppression and to formulate a theoretical base for its solution.

Keywords: freedom, Man, responsibility, participation, recognition, society.

\footnotetext{
${ }^{1}$ Národohospodářská fakulta, Vysoká škola ekonomická v Praze, nám. W. Churchilla 4, 13067 Praha 3,xmair900@vse.cz
} 


\section{Úvod}

Je nad vší pochybnost, že člověku jako subjektu a zároveň jako prvku socioekonomického systému není vždy zajištěno požívat status autonomního seberealizujícího se subjektu. Důvodem jsou především podmínky, do nichž jsou subjekty „uvrženi“; podmínky, jejichž předním účelem není autonomní seberealizující se subjekt. Autor vychází z přesvědčení, že boj za přetvoření těchto podmínek předpokládá radikální redefinici v oblasti společenské organizace, nebot' i přes domněle seberegulační mechanismy ekonomické oblasti, není systém ve své uzavřenosti schopen sebereflexe. Teoretická perspektiva tohoto přetvoření se stane onou bází, jež v důsledku povede k vysvobození člověka z okolností, které jej utiskují. Do značné míry se celá otázka dotýká obecné kategorie spravedlnosti, nebot' podmínky pouhopouhé účasti subjektů $\mathrm{v}$ rámci systému jsou definovány hodnotovým rámcem systému samotného. Může se tedy jevit jako nespravedlivé, když někteří $\mathrm{k}$ cílům autonomie, seberealizace a svobody směřovat smějí, zatímco druhým je tato cesta upřena a nepožívají reálné možnosti účasti - obsah jejich činnosti je ponížen na prostředek k přežití, proto i život těchto se stává pouhým samoúčelným prostředkem - žijí, aby žili.

Další obecnou kategorií zásadně ovlivňující svobodu subjektu je odpovědnost. V textu jsou diskutovány širší souvislosti tohoto pojmu v dnešní společnosti, nebot' i ten se stává funkčním prvkem zaběhnuté socioekonomické konfigurace. Souvislost s centrálním pojmem svobody se zdá býti nerozporná, nebot', jak je v následujících částech nastíněno, odpovědnost předpokládá svobodné jednání subjektu.

Mnozí se jistě pozastaví nad rozpravou o porobě subjektu v době dominujícího liberálněkapitalistického konceptu; v době největšího materiálního bohatství za celé dějiny lidstva; kdy se subjekty $\mathrm{v}$ rámci tohoto konceptu mohou oddávat veškerým mnohostem svých identit. Následující odstavce se přesto pokusí načrtnout nejzávažnější útoky na autonomii a svobodu subjektu v současné společnosti. Společenská dilemata jsou tak řešena $v$ obecných kategoriích, v nichž systém selhává vưči Člověku.

\section{Porobený subjekt}

Prvně je nutné vycházet $\mathrm{z}$ teze, že v liberálně-kapitalistické společnosti závisí do značné míry kvalita života subjektu na podmínkách trhu. Již na tuto skutečnost reaguje Stephan Voswinkel (2007:103-104), inspirován Gabrielem Wagnerem, když upozorňuje na nebezpečí, že se tímto subjekt stává objektem proměnlivých vnějších vztahů, které přetvářejí fluidní jáství dle externě určených potřeb (trhu). Na základě tohoto stanoviska se nabízí rozlišení i potřeb subjektu. Pokud bychom uvažovali jakési členění na potřeby objektivní a subjektivní, pak se v prvním př́padě jedná o biologické potřeby, nezávislé na vůli subjektu, jež podmiňují jeho samotnou existenci. $V$ druhém prŕípadě bychom pak mohli uvažovat potřeby nacházející se v preferenčním prostoru subjektu, tj. podtrhující jeho individualitu, která je formována/deformována vnějšími vztahy. Pokud již objektivně dané potřeby subjektu jsou předmětem organizace trhu, pak je subjekt „nucen“2 pro zachování své biologické existence podřídit se jeho podmínkám. Niklas Luhmann v této souvislosti mluví o „reflexivně kontrolované sebeprezentaci“ - subjekt je podněcován k řešení otázky ve vyhovění vnějším očekáváním či nárokům na něj kladeným. (Wosvinkel, 2007:105) Pokud se předmětem tržních vztahů stávají i tyto objektivní potřeby, subjekt pak nemá možnost uniknout

\footnotetext{
${ }^{2}$ Abraham Maslow zde mluví o homeostázy, tedy samočinném mechanismu všech živých organismů, který se automaticky snaží zachovat svůj príirozený stav. (MASLOW, 1943: 374)
} 
imperativům trhu a jeho subjektivita se dostává do rozporu s existenčními podmínkami jeho bytí.

Anarchokapitalistické proudy se domnívají, že socioekonomický řád má být výsledkem svobodně jednajících subjektů, tj. především těch subjektů, kterým není určováno co, kdy, kde, proč a jak mají dělat. Svoboda je tak vnímána pouze jako negativní vymezení. Takovými subjekty se dnes opravdu můžeme stát. ${ }^{3} \mathrm{Z}$ toho je pak zřejmé, že za oběhem kapitálu s cílem zisku stojí skuteční lidé $\mathrm{s}$ jejich schopnostmi a zdroji. Tímto se však přibližujeme lacanovskému rozlišení pojmů reality a Reálna. Jak uvádí Žižek (2007:295), je totiž nutné rozlišovat realitu jako společenskou skutečnost reálných lidí, vtažených do vzájemných interakcí a produkčních procesů, od Reálna, oné abstraktní logiky kapitálu určující děje ve společenské skutečnosti, tj. v realitě. Lze to analogicky přirovnat $\mathrm{k}$ Fisherově deskripci, když tvrdí, že korporace jsou pouhými „temnými aktéry v pozadí všeho“ a že jsou pouhou „manifestací a instrumentem instance, která sama není subjektem: Kapitálu“. (Fisher, 2010:92)

Lidské jednání tudíž podléhá určujícím podmínkám, v nichž se odehrává. Představy liberálněkapitalistických myslitelů jsou však redukovány pouze na oblast reality. Jednání formálně si rovných autonomních subjektů je pouze viditelnou, reálnou složkou, za níž stojí její vnější určení, jímž se v moderní době stává trh/kapitalismus/neoliberalismus...(Reálno). Tedy pouze ten subjekt se cítí svobodný, který si není vědom př́čin určujících jeho jednání. Svobodní ve svém jednání jsou jen ti, kteří nerozpoznávají/nepocit’ují prríčiny, jež je determinují.

Subjekty jsou zároveň nuceny přijmout jistou zodpovědnost. V jiných socioekonomických systémech je subjekt odpovědnosti zčásti zbaven, nebot' tu na sebe přebírá stát, strana, kmen či jiné instituce. Moderní subjekt se však nalézá v postavení, kdy přebírá odpovědnost za svůj osud, přičemž jeho osud je do značné míry předmětem systémové determinace ${ }^{4}$. Vzhledem $\mathrm{k}$ tomu, že míra odpovědnosti by se $\mathrm{z}$ principu měla ztotožňovat $\mathrm{s}$ mírou působení svého jednání, tj. kompetencemi, lze identifikovat další významný rozpor ve společenské konfiguraci. Vztaženo k sociální struktuře, jsme svědky situace, kdy nejvyšší společenské tř́idy mívají širší pole působnosti, než odpovědnosti, zatímco nižší společenské třídy „požívají“ vyšší míru odpovědnosti, než je jejich akční rádius. Jedná se tedy o imperativ učinit ze sebe odpovědného za něco, co jako individuum nemohu ovlivnit. Naopak privilegované společenské třídy mají kompetence ovlivňovat i oblasti, ve kterých nenesou společenskou odpovědnost. Imperativ odpovědnosti je, jak vyplývá již ze slovního spojení samotného, v rozporu se svobodným a odpovědným rozhodnutím, nebot' takové rozhodnutí se uskuteční pouze tehdy, když se subjekt sám do takovéto pozice rozhodne vstoupit. Kupř́ikladu Sophiina volba od Jamese Styrona je dle výkladu současného socioekonomického řádu svobodným rozhodnutím matky, za nějž nese zodpovědnost ${ }^{5}$, protože zde není reflektována

\footnotetext{
${ }^{3} V$ moderní společnosti dokonce můžeme sledovat tlaky, aby člověk prijial svou svobodu a stal se subjektem. Jak uvádi Louis Althusser, tento proces je součástí struktury systému a prijietím subjektivity se stáváme jeho funkčním prvkem. Subjektivita se tak stává formou ideologie. ALTHUSSER, L., Ideology and Ideological State Apparatuses. In HAUSER (2007: 147) Takovéto pojetí subjektivity je ovšem záhodné vnímat rovněž jako přenesení odpovědnosti na subjekt samý, kdy jsou selhání přiznány nikoli systému a jeho podmínkám, nýbrž konkrétním subjektům prijímajících subjektivitu, viz dále.
}

${ }^{4}$ Pomin̆me zde vlivy nesystémové či stochastické, např. do jakého rodinného zázemí se subjekt narodil.

${ }^{5}$ Právě tíha odpovědnosti/viny vede Sophii k sebevraždě. 
zvnějšku určená pozice subjektu. Nikdo nenutí Sophii, aby se rozhodla tak či onak, je to čistě její svobodné rozhodnutí. Z autonomního subjektu se však nakonec stává prostředek uskutečnění akceptující vnější (libo)vůli Fritze Jemanda von Niemanda ${ }^{6}$, trhu, strany, státu apod. V př́padě zvnitřnění této vůle se přirozeně deformuje/zaniká autonomie subjektu, nebot' subjekty se tím stávají pouhými prostředky uskutečnění akceptující onu vnější libovůli absolutní moci.

Internalizaci vnější vůle se věnuje i Slavoj Žižek. Využívá Beauvoisovu analýzu režimů a dochází k závěru, že autoritářský režim si vynucuje poslušnost jednoduchým imperativem pod hrozbou trestu apod. Totalitární režim se při konání svých cílů odvolává na vyšší princip, čili vykonání služby je ku prospěchu lidstva, strany, národa apod. Liberální režim se obrací, stejně jako totalitární, na subjekt, avšak apeluje v jiném duchu. Klade důraz na vnitřní ztotožnění subjektu s cílem režimu: „Liberalismus je znich (...) nejhorší, protože naturalizuje di̊vody k poslušnosti tím, že je integruje do vnitřni psychologické struktury subjektu. Největším paradoxem je tudiž to, že „liberálni" subjekty jsou svým zpưsobem ty nejméně svobodné: mění samotný svůj názor/pohled na sebe samé, když uznávají to, co jim bylo vnuceno, jako spontánní výraz své „přirozenosti“ - nejsou si dokonce již ani vědomi svého podřizeného postavení. " (2009:173)7

Zastavme se ovšem i u Žižekova pojetí odpovědnosti ve vztahu k svobodě. Kritizuje nátlak vyvíjený na subjekt, aby se svobodně rozhodoval a nesl odpovědnost za svá rozhodnutí, která je nucen učinit bez reálné znalosti situace. Doslova píše: „Svoboda rozhodování, kterou má subjekt v „rizikové společnosti“ neni svobodou člověka, který může svobodně volit svůj osud, nýbrž úzkost, vyvolávajicí svoboda někoho, kdo je bez přestání nucen činit rozhodnutí, aniž si uvědomuje jejich následky. " (Žižek, 2007:360-361) Nezrcadlí se tu snad př́běh Josefa K. z Kafkova Procesu, který ač ponechán na svobodě je sankcionován za jemu neznámá provinění, a kde každý jeho krok znamená zodpovídání se neznámé instanci za předešlá rozhodnutí, o jejichž důsledcích nemá a neměl ponětí, ba dokonce ani neví, o jaká rozhodnutí se jedná? Dnešní subjekt zažívá podobnou formu svobody, jakou požíval Josef K. v době svého procesu, tedy bez možnosti vstoupit do ,procesu“, tj. do sféry určujících podmínek, které na něj systematicky působí. Subjekt totiž stojí před Foucaultovým „permanentním ekonomickým tribunálem", oním Reálnem, proti kterému nelze vystoupit; které, dnes na základě míry zisku, rozhoduje o bytí a nebytí.

Tímto se dostáváme k paradoxním poznatkům Klause Günthera (2007:171-172). Inspirován př́mými výpověd’mi účastníků přispěl $\mathrm{i}$ on $\mathrm{k}$ unikátní analytické perspektivě ve vztahu odpovědnosti a svobody. Na příkladu masochismu totiž uvádí, že člověk dobrovolně vstupuje do stavu podmanění, jedná se o "odpovědný vstup do stavu neodpovědnosti”, v němž je ztráta odpovědnosti osvobozením. Člověk není odpovědný za to, co dělá; $\mathrm{k}$ činnostem je nucen a osvobození se tak uskutečňuje skrze prožitek kázně, poslušnosti, závislosti a nátlaku.

Další závažnou ambivalenci svobody při vnímání subjektu ve vztahu k Vnějšku ${ }^{8}$ nalézáme u Georga Simmela. Již ve své Philosophy of Money jasně říká, že subjekt ${ }^{9}$ sice získal svobodu,

\footnotetext{
${ }^{6}$ Stingem pojmenovaný německý lékař, který v knize Sophiina volba donutí Sophii rozhodnout, které z jejích dětí pošle na smrt.

7 Tato citace neslouži k obhajobě explicitně represivních režimů, nýbrž k definování prostoru, v rámci nějž liberální společnosti uplatňují imperativy.

${ }^{8}$ Jako podmínek reality a Reálna.

${ }^{9} V$ tomto prípadě použil Georg Simmel slovo „peasant“, čili rolník.
} 
ale pouze část jejího obecného vzoru. Jedná se o svobodu od něčeho, nikoliv $k$ něčemu, jejímž zdáním je svoboda ke všemu. ${ }^{10}$ Zdáním je proto, že tato část svobody je negativní a bez jakéhokoli určitého a určeného obsahu. (2005:405) Dle liberálně-kapitalistické doktríny, neobsahující oblast $k$ něčemu ${ }^{11}$, tak může být svobodným i hladový, nemocný a nevzdělaný člověk. Dnes je tak naprosto běžné, že člověk je považován za svobodného, dokonce se tak i cítí, pokud je zproštěn vnějších zásahů. Michael Hauser uvádí na příkladech učitele, vědy či umění, že na subjekt mohou svou podmanivostí a přesvědčivostí působit jako vnější zásahy, omezující jeho svobodu. To vytváří nenávist k rozumu, umění i k lidem, nebot' vše je chápáno jako potenciální ohrožení svobody. Takto pojatá svoboda je v důsledku stavem odcizení všem obsahům i lidem. Takový člověk není schopen rozvíjet tvůrčím a kritickým způsobem vztah k něčemu pozitivnímu, obecnému. (2007:181)

Poslední zamyšleníhodný př́íspěvek této části pochází od Wendy Brown ${ }^{12}$, která se pokouší formulovat sloučení autoritativního režimu a individuální volby. Dnes dochází ve velkém k zcela zkreslenému jednání - zaujetí volbou a uspokojování různorodých potřeb v preferenčním poli je zaměňováno za svobodu. Řešení svých osobních dilemat tak subjekt nachází $\mathrm{v}$ produktech, přičemž neuniká autoritářskému mechanismu vnější moci. V závěru této části je př́značné citovat Johna Graye, nebot' ,jsme nuceni žit tak, jako bychom byli svobodni". (2007:110)

\section{Nástroje emancipační teorie}

\section{Princip participační parity}

Za účelem rožrešení výše uvedených dilemat lze využít principu participační parity, který rozpracovala Nancy Fraser a který se týká obecného pojmu spravedlnosti. Podle tohoto principu je spravedlivá ta společnost, která umožňuje všem (dospělým) jedincům vztahovat se k sobě navzájem jako rovný k rovnému. (Fraser, 2007:15) Hledání spravedlivé společnosti je v jejím pojetí syntézou uznání, pro egalitáře pouhou „nadstavbou“ distributivní spravedlnosti, a prerozdělování, jež je pro oponenty naopak staromódním materialismem a reduktivním ekonomismem. Obě paradigmata - jak uznání, tak přerozdělování - ovšem navzájem redukují své významy. Např́íklad pokud jde o nerovnoměrné rozdělování zdrojů, které dle výkladu Nancy Fraser nedokáže paradigma uznání uspokojivě uchopit a tak jej marginalizuje, nebo naopak př́pady statusové hierarchie či institucionálního zneuznání, jež naopak nedokáže uchopit distributivní paradigma. Její strategie ovšem nespočívá v přiklonění se k jedné či druhé cestě spravedlnosti, nýbrž usiluje o jejich skloubení.

Z vymezené oblasti diskutovaných dilemat tedy vyplývá, že v pojetí Fraserové pravidla ekonomiky způsobují distributivní nespravedlnosti a že kulturní hodnotové vzorce generují statusové nerovnosti a zneuznání. Tato paradigmata byla následně rozpracována do

\footnotetext{
${ }^{10}$ Podobně rozlišoval Robert Nozick $v$ díle Anarchie, stát a utopie práva na negativní - požadavek, aby tato práva nikdo neomezoval, a na positivní - vztahující se $k$ požadavku, abych něco obdržel.

${ }^{11}$ Vrcholné až obscénní soustredění na definování svobody ve smyslu "od něčeho" prezentuje predstavitel Rakouské školy Murray Rothbard. Tvrdí, že dokud děti neopustí domov, rodič "nemá právo dopustit se vůči svým dětem agrese, ale také by rodič neměl mít zákonnou povinnost své děti krmit, oblékat nebo vzdělávat, jelikož takové povinnosti by měly za následek vynucení pozitivních úkonů na rodiči a odepření jeho práv. Rodič tedy nemůže zavraždit nebo zmrzačit své dítě...(ale měl by) mít zákonné právo dítě nekrmit, tj. nechat ho zemřít." (2002:100)

${ }^{12}$ BROWN, W., American Nightmare: Neoliberalism, Neoconservatism and De-Democratization. In FISHER (2010:82)
} 
trojdimenzionálního modelu, který rozššřil oblasti přerozdělování a uznání o oblast reprezentace (rámce), nebot' , reprezentace je vždy inherentně přitomna ve všech nárocích na přerozdělování a uznání. Politická dimenze je implicitně př́tomna v gramatice konceptu spravedlnosti, a je jím dokonce vyžadována“. (Fraser, 2007:166) V rozsahu socioekonomického utrpení ve světě se tedy nabízí revidovat pozici kdo je oním subjektem spravedlnosti. V rámci každého z paradigmat navíc rozlišuje opatření na afirmativní a transformativní. Afirmativní opatření se zaměřují na konečný výsledek, napravení nespravedlností sociálního uspořádání bez narušení základní struktury systému. Tato opatření nabírají v oblasti distributivní spravedlnosti podobu sociálního státu, v politice uznání se jedná o multikulturalismus. Transformativní opatření nabírají v oblasti distributivní spravedlnosti podobu socialismu, v politice uznání směřují $\mathrm{k}$ dekonstrukci. ${ }^{13} \mathrm{~V}$ případě rámce lze afirmativní opatření chápat jako revizi současných hranic národních států, přičemž stále předpokládá národní stát jako výchozí bod analýzy, na rozdíl od opatření transformativních. ${ }^{14}$

Podrobnější vysvětlení principu participační parity je podáno v závěru knihy Rozvíjení radikální imaginace: „Tento princip má dvoji kvalitu, která vyjadruje reflexivní charakter demokratické spravedlnosti. Na jedné straně je princip participačni parity koncepcí výsledku - specifikuje principy obsahu spravedlnosti, pomocí nichž lze hodnotit sociální uspořádání: principy spravedlnosti jsou spravedlivé tehdy a jen tehdy, když dovolují všem relevantním sociálním aktérům rovnoprávně participovat na sociálním životě.“ (Fraser, 2007:178) Druhou kvalitu popisuje jako koncepci procesu, specifikující ,procedurálni standard, pomocí něhož lze hodnotit demokratickou legitimitu norem: normy jsou legitimní tehdy a jen tehdy, když mohou povzbuzovat souhlas všech zainteresovaných ve férových a otevrených procesech deliberace, jichž se mohou všichni rovnoprávně účastnit." (Tamtéž) Participační parita jako teorie spravedlnosti tak obsahuje inherentní reflexivitu spočívající v tom, že dokáže problematizovat jak obsah, tak i proceduru.

Při implementaci participační parity by tedy reformní entita musela prokázat, že navrhované nápravy nespravedlnosti v oblasti přerozdělování vytvoří objektivní podmínky plnohodnotné účasti těch, kteří jsou z participace $\mathrm{z}$ ekonomických důvodů vyloučeni, a to vše za předpokladu, že neospravedlnitelně nevytváŕí disparity jiných skupin. Stejně tomu tak je i v prrípadě uznání, čili reformní kroky v oblasti sociokulturně institucionální změny podpoří intersubjektivní podmínky, aniž by podporovaly jiné disparity. (Fraser, Honneth, 2004:66-67) Tyto principy určitým způsobem navazují na Paretovu optimalitu. Zásadní distinkcí je ovšem skutečnost, že princip participační parity je orientován kvalitativně, nikoliv kvantitativně. Pokud například na základě přerozdělovacího mechanismu bohatší občan odevzdá určitou část svého bohatství ve prospěch chudších obyvatel, je tak učiněno v rozporu s paretovskou optimalitou. Avšak pokud nejsou narušeny jeho objektivní podmínky plnohodnotné účasti a zároveň se posílí objektivní podmínky plnohodnotné účasti druhých, jednání je v souladu s principem participační parity.

Někteří členové ve společnosti pochopitelně zakouší nemožnost participovat na sociálním životě jako rovní s rovnými. Prvním z uváděných důvodů je extrémně nerovná distribuce

\footnotetext{
${ }^{13}$ Dekonstrukce jako transformativní strategie usiluje o destabilizaci binární pozice ve společnosti, např. muž/žena, heterosexuál/homosexuál, místní občan/imigrant atp. (FRASER, 2007:12-13)

${ }^{14}$ Zde Ize prĭipomenout apel Williama Robinsona, který si všímá charakterů spojení v globalizovaném světě. Tvrdí, že je nutné myslet spiše ve vztazích, nikoliv v kategoriích, nebot' vztahové myšlení sleduje entity či procesy v jejich vzájemném působení, zatímco kategorické myšlení sleduje jevy samy o sobě a isolovaně. ROBINSON (2009:179) Pokud vzpomeneme napřiklad na klimatické podmínky či informační technologie, je zřejmé, že spíše než do prostoru lokalit náleží tyto oblasti do prostoru tokù.
} 
materiálních zdrojů, jež znemožňuje v interakci s druhými vystupovat jako rovný s rovnými. Tato omezení jsou spojena s problematikou třídní struktury. Druhým důvodem nerovné participace ve společnosti mohou být institucionalizované kulturní hodnotové vzorce a jejich hierarchie. Tato omezení naopak odkazují na statusový řád. (Fraser, 2007:15, 157) Celá koncepce se tak dostává do jisté cirkularity, která však není dle výkladu Nancy Fraser způsobena pojmovým deficitem, nýbrž reflektivním charakterem tohoto pojetí spravedlnosti, který chápe uznání a přerozdělování jako rozdílné, avšak neoddělitelné pojmy. Princip participační parity tak dotváří komplex, v němž se odlišné dimenze spravedlnosti uznání a přerozdělování neredukují jedna na druhou, nýbrž se doplňují a tím vytvářejí předpoklady pro „fraserovský“ výklad radikální demokracie.

\section{Tripolární teorie spravedlnosti a dimenze morálního pokroku}

Axel Honneth považuje současný stav socioekonomického uspořádání za „ostudný“ a přisuzuje normativnímu hledisku spravedlivého rozdělování životně důležitých statků nejvyšší prioritu. (Fraser, Honneth, 2004:148) Na rozdíl od Nancy Fraser se však domnívá, že namísto syntézy materiálních a kulturních úvah o spravedlnosti by měl nastoupit jednotný rámec pojmu uznání. Ten je $\mathrm{v}$ jeho pojetí diferencovaným kategoriálním rámcem, v němž vidí pojmové spojení mezi sociálními prřčinami široce rozšířené nespravedlnosti a normativními cíli emancipačního hnutí.

V př́ípadě Axela Honnetha je vhodné se pozastavit u nespravedlností, jež mají původ v procesech s adjektivem „sociální“. Tyto nespravedlnosti vznikají jako neuspokojení normativních očekávání, „o kterých se dotčeni domnívají, že je oprávněné směrovat je na společnost “. Jinými slovy se jedná o bezpráví, jehož institucionalizovanou úpravu si subjekt nedokáže racionálně vysvětlit. Subjekty si tak uvědomují sociální bezpráví tehdy, když tyto institucionalizované úpravy ,, zneuznávají aspekty jejich osobnosti, o nichž se domnívají, že na jejich uznání mají právo“. (Fraser, Honneth, 2004:168-169) Základní pojmy vyjadřující dimenzi sociálního bezpráví tak musejí odpovídat normativním očekáváním, které subjekty ztotožňují se sociálním uznáním své osobní integrity. (Fraser, Honneth, 2004:171-173) Za zásadní legitimizační ${ }^{15}$ instanci v kapitalistické společnosti považuje výkon, který princip participační parity povětšinou vztahuje k paradigmatu přerozdělování. Nebot' je to právě kritérium výkonu, které posiluje svou pozici a expanduje i do oblastí, které byly dosud organizovány na principech potřebnosti či nároku. ${ }^{16}$

Pokud se přidržíme oblasti obecné sociální spravedlnosti, v Honnethově pojetí nalézáme tři zásady (Fraser, Honneth, 2004:226-227): zásada lásky, zásada rovnosti a zásada zásluhy, čímž vytváří jakousi tripolární teorii spravedlnosti. Stojí za připomenutí, že ústřední ideou Nancy Fraser je princip participační parity, jemuž se společnost přibližuje prostřednictvím zrušení kulturního ponížení a ekonomické nerovnosti. Kritická připomínka německého profesora spočívá $\mathrm{v}$ tom, že jeho koncepce uznání ,váže možnost utváření identity na předpoklad účasti na sociálních interakcích, a přiznává tedy vysoký význam participaci ": jde tedy o to, aby byl subjekt schopen bez nátlaku rozvíjet potenciál své vlastní osobnosti, a tím rozvíjet svou osobní identitu v prostředí, jež mu umožňuje plnohodnotně vystupovat na veřejnosti. (Fraser, Honneth, 2004:227-228)

\footnotetext{
${ }^{15}$ Legitimizační ve smyslu ospravedlňování zjevných nespravedlností, zejména nerovné rozdělování zdrojů na bázi výkonu.

${ }^{16}$ Viz vláda Petra Nečase, která pod rouškou modernizace zavedla tzv. veřejnou službu, podmiňující vyplácení sociálních dávek - obsahujíce jak dimenzi potřebnosti, tak dimenzi nároku - vykonáváním práce neboli podáním výkonu. Ústavní soud České republiky zrušil veřejnou službu dne 27. 11. 2012.
} 
Jak je to ale s tripolárním pojetím spravedlnosti u Axela Honnetha? Vychází z toho, že $\mathrm{k}$ individuální autonomii subjektu dochází prostřednictvím uznání jeho potřebnosti, právní rovnosti a sociálních př́spěvků. Axel Honneth kontextualizuje tyto oblasti a udává př́klady jejich aplikace dle sociálního vztahu mezi subjekty. Např́klad vztahy formované dovoláváním se lásky upřednostňují princip tužeb; pro právně formované vztahy má přednost zásada rovnosti a kooperativní vztahy se vyznačují platností principu zásluh. (Fraser, Honneth, 2004:234) Tripolarita spravedlnosti dle Axela Honnetha však není odvozena z empirických výsledků zkoumání spravedlnosti, ani sociálně ontologického rozlišování sociálních vztahů, nýbrž z podmínek utváření identity. (Fraser, Honneth, tamtéž) Jeho prrístup není postaven do takové míry a primárně na distributivní logice, ale na různých formách uznání, z kterých následně a zprostředkovaně vyplývají distributivní aspekty. Jedná se tedy o zakomponování primárně morálních ohledů v rámci strategie ochrany podmínek osobní integrity subjekti̊.

Jako přední dimenzi morálního pokroku v sociálních vztazích uvádí individualizaci a sociální inkluzi: kvalita sociální integrace se zvětšuje posílením „uznaných“ osobních podílů, ve vzájemném uznávání se uplatňují nové podíly osobnosti a roste míra sociálně potvrzené individuality; druhým př́ípadem je posílená inkluze individuí do existujících vztahů uznání, čímž se rozšiřuje okruh vzájemně se uznávajících subjektů. ${ }^{17}$ (Fraser, Honneth, 2004:238-239) Tyto dvě dimenze se prolínají v pojetí uznání, nebot' k zahrnování členů do společnosti dochází tím způsobem, že se jedinci učí ,,intersubjektivně se potvrzovat v určitých ohledech nebo fasetách své osobnosti“. (Fraser, Honneth, 2004:310) Jinak řečeno subjekty jsou integrovány do společnosti tím, že se vnímají jako sociálně uznané subjekty.

\section{Dilemata svobody a perspektivy východisek při jejich řešení}

V rámci třetí generace frankfurtské školy byly vypracovány teoretické nástroje uvedené $\mathrm{v}$ předchozí části, jež se nabízejí pro řešení dilemat zmíněných v části první. Jedním z mezikroků spravedlivé společnosti, na níž se soustředí jak princip participační parity, tak teorie tripolární spravedlnosti, jsou právě otázky týkající se svobody a autonomie subjektu. Jinak řečeno nelze dosáhnout spravedlivé společnosti ve smyslu Fraserové či Honnetha, aniž by subjekty nepožívaly skutečných svobod. Oba autoři překračují nedostatečný liberálněkapitalistický monismus ve výkladu svobody a autonomie, nebot' nad rámec formálních svobod a spravedlností uchopují pojem svobody substanciálně, tedy vztahují jej k výsledku.

Nyní tedy k perspektivě řešení z pohledu emancipačních teorií. Jako první vyvstává otázka, $k d o$ je vủbec subjektem skutečných svobod. Zde lze využít jak principu participační parity, tak teorie tripolární spravedlnosti. V prvním př́padě dochází k zakomponování otázky rámce, který ony subjekty definuje. Podobně i v druhém př́padě, kdy Honneth označuje sociální inkluzi, tedy zahrnování subjekti̊ do existujících vztahů uznání, jako jednu z dimenzí morálního pokroku. Jde tedy o to maximalizovat okruh vzájemně se uznávajících subjektů, respektive stanovit nejširší možný rámec pro aplikaci principů participační parity. To předpokládá abolici všech kulturních a ekonomických ${ }^{18}$ důvodů exkluze subjektů, respektive uznání subjektu ve své obecnosti - jako Člověka; subjekt je zahrnut do společenských vztahů proto, že je Člověk.

\footnotetext{
${ }^{17}$ Zde je patrná analogie na pojetí Nancy Fraser a jejích požadavků na participační paritu a míru inkluzivity, viz Fraser (2007:141).
}

${ }^{18}$ Axel Honneth by dodal, že nejen těchto. 
Po vyřešení této otázky se nabídne otázka další, v Honnethově pojetí morálního pokroku se jedná o druhou dimenzi, tedy o otázku individualizace. Ta doplňuje sociální inkluzi, nebot' individualizace posuzuje kvalitu sociální integrace, která se zvětšuje posílením „uznaných“ osobních podílů - ve vzájemném uznávání se uplatňují nové podíly osobnosti a roste míra sociálně potvrzené individuality. $\mathrm{V}$ prrípadě participační parity jde o vytvoření objektivních podmínek plnohodnotné účasti těch, kteř́i jsou z participace z ekonomických důvodů vyloučeni; podobně tak i v oblasti sociokulturně institucionálních změn podporujících intersubjektivní podmínky.

V textu byla zmíněna postava Josefa K. z Kafkova Procesu. Tato postava znázorňuje vztah subjektu k neuchopitelnému Vnějšku. Neuchopitelná instance je mu zprostředkovávána skrze různé reality - reprezentanty oné vnější moci. Další postavou nastíněnou v předchozích odstavcích byla Sophie Zawistowska. Tato postava je extrémním vyobrazením toho, jak subjekty jednají v konkrétní realitě. Sophie tím, že byla Polka, nikoli židovka, požívala právě této výsady jednat - svobodně vyjádřit volbu zda Jan či Eva. Dnešní subjekt se nachází v podobné situaci - bud' se podvolí podmínkám přivlastňování zdrojů a ztratí část svého Já (podobně jako Sophie ztratila Evu), nebo zůstane bez zdrojů. ${ }^{19}$ Není nikým nucen at' k té či oné variantě, může si svobodně vybrat. Podmínky rozhodnutí však nejsou ztvárněny konkrétností libovůle onoho Fritze Jemanda von Niemanda, ale systematickou, neuchopitelnou instancí Vnějšku, které čelí Josef $\mathrm{K} .{ }^{20}$ Ač se tedy jedná o svobodnou volbu, subjekt do ní svobodně nevstupuje a je mu určena z nadsmyslového Vnějšku. Právě tato a další dilemata se nabízí řešit emancipačními nástroji frankfurtské školy.

Začněme možnostmi participace ${ }^{21}$ subjektu ve společnosti. Pojem participace do značné míry ovlivňuje všechna řešená dilemata $v$ oblasti svobody a odpovědnosti. Pokud máme vyřešenou otázku rámce/míry inkluze, tedy je zřejmé, kdo je subjektem emancipačních opatření, dostáváme se k vertikálním kvalitám těchto opatření. Právě substanciálně uchopený pojem participace znamená možnost vstupu do podmínek determinujících vlastní jednání. V podstatě se jedná o možnost participovat na formulaci samotných podmínek. Dosud byly subjekty odtrženy od podmínek jejich určení (podobně jako Josef K.); mohly se tedy svobodně rozhodovat (podobně jako Sophie Zawistowka), avšak v předem stanoveném horizontu vládnoucích tezí. V emancipačním pojetí se tedy dostáváme k tomu, že subjektu samotnému je umožněno formulovat ,pravidla hry“, v rámci nichž se bude jeho jednání odehrávat. Takto lze definovat i substanciálně uchopený pojem svobody - subjektu je umožněno nejen pouhé pasivní rozhodování v definovaném výběru, nýbrž je aktivním prvkem při sestavení výběru. Tím se zároveň řeší problém odpovědnosti, protože lidé svobodně a dobrovolně vstupují do podmínek, jež sami spoluutvářeli. V takovém př́ípadě nesou plnou odpovědnost za své jednání. Tu však lze jen stěží vyžadovat po těch, kteří byli uvrženi do podmínek společenské

\footnotetext{
${ }^{19}$ Dalši možnost nastává, když se vnitřní zájem subjektu překrývá s imperativy Vnějšku. Pak je vlastní sebeuskutečnění možné současně při prívlastňování zdrojủ. Otázkou ovšem zůstává, zda zájem subjektu je opravdu jeho vnitřním zájmem, či zda se jedná o internalizaci požadavků vnějších sil, které na něj působí.

${ }^{20}$ Jinak řečeno Sophie čelí spíše realitě, Josef K. spíše Reálnu.

${ }^{21}$ Touto otázkou se zabývá i Honneth, nebot' jak uvádí, jeho koncepce uznání „váže možnost utváření identity na předpoklad účasti na sociálních interakcích, a přiznává tedy vysoký význam participaci“: jde tedy o to, aby byl subjekt schopen bez nátlaku rozvíjet potenciál své vlastní osobnosti, a tím rozvijet svou osobní identitu v prostředí, jež mu umožňuje plnohodnotně vystupovat na veřejnosti. (Fraser, Honneth, 2004:227-228)
} 
organizace bez možnosti ovlivnění takových podmínek. Subjekty tak nebudou zatíženy falešným pocitem odpovědnosti, jež vedl Sophii k sebevraždě.

Aby byla kategorie svobody naplněna v duchu nastíněném Georgem Simmelem, je nutné svobodu formulovat taktéž positivně, tedy jako právo $k$ určitému obsahu. Pokud v rámci reprezentace (rámce) definujeme subjekty jakožto Člověka ve své obecnosti, nabízí se řešení v oblasti objektivních potřeb člověka. Např́íklad pokud se subjekt chce udržet při životě, předpokládá se jeho asimilace na trhu, nebot' odtud získává prostředky svého přežití. Jestliže se zaměříme na nejčastější zdroj těchto prostředků, tedy trh práce, můžeme konstatovat, že tento trh není organizován pro účely subjektů jako lidí, není organizován na základě jejich schopností a svobodné vůle, ale na nutnosti subjektů prodávat svou pracovní sílu za mzdu. Za př́padný neúspěch na trhu práce nese odpovědnost subjekt samotný, nebot' nedokázal dostatečně formovat/deformovat své vlastní Já pro potřeby trhu. Pokud by tedy byla zajištěna důstojná existence subjektu bez ohledu na to, zda uplatňuje své schopnosti na trhu, získal by subjekt druhou část opomíjené svobody, tedy $k$ určitému obsahu - k zajištění jeho existence aniž by se musel podřizovat fluidním potřebám Vnějšku. Tím lze dospět k eliminaci deformací autonomie subjektu, nebot' subjekt si zachovává své vlastní Já - není nucen k reflexi své zvnějšku určené pozice; uspokojení jeho objektivních potřeb je mu zaručeno. $\mathrm{K}$ tomu dochází přednostně v Honnethově pojetí uznání - subjekt získává svou subjektivitu tím, že je uznán jako Člověk ve své obecnosti a takto uznává i ostatní. $Z$ toho následně vyplývají distributivní prvky v oblasti zdrojů.

Jedná se tak o materialistické stanovisko, přestože vychází z Honnethovy, a tedy Hegelem inspirované artikulace pojmu uznání. I proto lze předpokládat, že řešení soudobých dilemat v oblasti svobody subjektu bude vycházet z teze, že hmota předchází ideu. Zastánci opačného názoru mohou tvrdit, že motivy vedou subjekt k činům. Kupř́ikladu touha po svobodě může vést k obětování života, kdy ono bytí je právě v abstraktním pojmu svobody, nikoli v materii lidského těla; materie je závislá na ideji. V takovém př́padě se jedná o svobodný vstup subjektu do rozhodovacího procesu ohledně vznešených cílů. Co je však nutné, aby tento vstup byl opravdu svobodný? Subjekt se může vzdát své biologické existence ve prospěch svých ideálů, jediné co $\mathrm{k}$ tomu potřebuje je protipól, kterým je možnost zachování své existence. Ušlechtilé činy romantických hrdinů jsou hrdinské právě tím, že navzdory možnosti zachování své existence se hrdina na základě svých morálních kvalit rozhodne zemřít. Hrdinou by nebyl těžce nemocný člověk, který se těsně před svou smrtí upálí na protest proti nelegitimní vládě. Jde tedy o to, že i nejvyšší forma idealistického jednání (obětování života/hmoty ve prospěch ideálu/ducha) nutně předpokládá možnost zachování života. Tímto lze opět klást důraz na Člověka v jeho objektivních potřebách.

Emancipační nástroje třetí generace frankfurtské školy tak přicházejí s unikátní perspektivou nejen jak rozpory současné socioekonomické konfigurace identifikovat, ale nastiňují i nové dimenze, v nichž lze rozpory řešit. Diferencované pojetí uznání dle Axela Honnetha se vztahuje k morálně-filosofickému postavení subjektu ve společnosti. Usiluje o nejvyšší možné uznání individuality při nejvyšší míře inkluze subjektů do existujících vztahů uznání. Tímto př́istupem lze obsáhnout Člověka ve své obecnosti, snad by se dalo říci až přirozenosti (v jeho objektivních potřebách), na základě čehož všechny subjekty konstituují svou individualitu. Princip participační parity může přispět například v procedurální sfére, kdy se jednotlivé reformní kroky posuzují z hlediska tvorby objektivních podmínek plnohodnotné účasti subjektů ve společnosti, což v důsledku přispívá k řešení nastíněných otázek svobody a odpovědnosti. 


\section{Závěr}

Tento text se zabývá široce pojatým pojmem svobody subjektu. Cílem bylo poodkrýt možné strategie pro schopnost subjektu bez nátlaku rozvíjet potenciál své vlastní osobnosti, a tím rozvíjet svou osobní identitu v prostředí, jež mu umožňuje plnohodnotně vystupovat ve veřejném prostoru. Stejně tak jde o budování individuální autonomie subjektu skrze uznání jeho potřebnosti, právní rovnosti a sociálních př́spěvků. Jinými slovy text řeší rozvíjení podmínek svobody subjektu pomocí emancipačních nástrojů třetí generace frankfurtské školy.

Soudobý liberálně-kapitalistický systém vedl k rozšíření svobody rozvoje svých bytostných sil, nikoliv však k universalizaci této svobody, která stále zůstává výsadou privilegovaných tříd. Proto je zavádějící mluvit o svobodě a demokracii, přestože krok směrem k těmto ideálům byl učiněn. I proto je kladen důraz na uchopení subjektu v jeho obecnosti, jež má vést $\mathrm{k}$ abolici př́ććin jeho exkluze a zároveň se má stát argumentem jeho inkluze. Jedná se tak o prosazení obecnosti vůči partikulárnímu; zohlednění společného lidství vůči privilegiím. V prvním kroku se nabízí horizontální rozšiření navzájem se uznávajících subjektů. Druhým krokem je kvalitativní, vertikálně orientované prohloubení svobod mezi vzájemně se uznávajícími subjekty. Právě skrze nástroje frankfurtské školy lze dospět k řešení zastřených otázek svobody, nebot' kombinací paradigmat Nancy Fraser a Axela Honnetha lze vymanit subjekt ze závislé situace, kdy se stává objektem proměnlivých tržních vztahů, na nichž jsou závislé jeho objektivní podmínky přežití.

Rozpor mezi Axelem Honnethem a Nancy Fraser vidí autor po značném zjednodušení spíše $\mathrm{v}$ teoretické bázi obou autorů, než ve věcném obsahu. V zásadě se jedná o to, zda z uznání určité kategorie vyplývají i distributivní prvky (Honneth), či zda se jedná o oddělené oblasti, jejichž řešení vyžaduje různé teoretické báze (Fraser). Oba se však shodují v tom, že nejvyšší priorita náleží normativnímu hledisku spravedlivého rozdělování životně důležitých statků. Jedná se tak o zajištění toho nejzákladnějšího, což zároveň nemusí být automaticky v silách samotného subjektu, a který se tak oprávněně domáhá svých nároků u společnosti.

Pro docílení skutečně svobodných subjektio, jejichž jednání uniká systémové determinaci, je nutná redefinice již základních pozic. Člověk nebude svobodný, dokud si nepodmaní ony socioekonomické zákony, interpretované jako neměnná, ahistorická substance; jako př́rodní zákony mimo lidský svět.

\section{Literatura}

FISHER, Mark. Kapitalistický realismus. Praha: Rybka Publishers, 2010. 107 s. ISBN 978-80-87067-69-7.

FRASER, Nancy. Rozvíjení radikálni imaginace. HRUBEC, Marek ed. 1. vyd. Praha: Nakladatelství Filosofického ústavu AV ČR, 2007. 184 s. ISBN 978-80-7007-251-6.

GRAY, John. Straw Dogs: Thoughts on Humans and Other Animals. 1st edition. Paperback. New York: Farrar Straus and Giroux, 2007. 272 p. ISBN 978-03-74270- 93-3.

GÜNTHER, Klaus. Mezi zmocněním a disciplinováním. Odpovědnost v současném kapitalismu. In HONNETH, Axel ed. Zbavovat se svéprávnosti: Paradoxy současného kapitalismu. 1. vyd. Praha: Nakladatelství Filosofického ústavu AV ČR, 2007. 334 s. ISBN 978-80-7007-269-1.

HAUSER, Michael. Prolegomena k filosofii současnosti. 1. vyd. Praha: Nakladatelství Filosofického ústavu AV ČR, 2007. 200 s. ISBN 978-80-7007-270-7.

MASLOW, H. Abraham. A Theory of Human Motivation. Psychological Review, 1943, vol. 50, s. $370-396$. Internet Resource by GREEN, D. Christopher. York University, 2000. Toronto, Ontario. ISSN 1492-3713. 
ROBINSON, I. William. Teorie globálního kapitalismu: Transnacionální ekonomika a společnost $v \quad k r i z i .1$. vyd. Praha: Nakladatelství Filosofického ústavu AV ČR, 2009. 364 s. ISBN 978-80-7007-305-6.

ROTHBARD, N. Murray. The Ethics of Liberty. Dotisk. New York University Press, 2002. 308 s. ISBN 0-81477559-4.

SIMMEL, Georg. The Philosophy of Money. 3. rozšířené vyd. Great Britain: Taylor \& Francis e-Library, 2005. 543 s. ISBN 0-203-68069-3.

VOSWINKEL, Stephan. Obdiv bez ocenění? Paradoxy uznání dvojnásobně $\quad$ subjektivizované $\quad$ práce. In HONNETH, Axel ed. Zbavovat se svéprávnosti: $\quad$ Paradoxy současného kapitalismu. 1. vyd. Praha: Nakladatelství Filosofického ústavu AV ČR, 2007. 334 s. ISBN 978-80- 7007-269-1.

ŽIŽEK, Slavoj. Podkova nade dveřmi: Výbor z textů. 1. vyd. Praha: Vědecko-výzkumné pracoviště AVU, 2009. 220 s. ISBN 978-80-87108-10-9.

ŽIŽEK, Slavoj. Nepolapitelný subjekt: Chybějicí střed politické ontologie. 1. vyd. $\quad$ Chomutov: L. Marek, 2007. 440 s. ISBN 978-80-87127-02-5. 